\title{
LXI. Removal of the voltaic potential-difference by heating in oil
}

\section{J. Brown F.R.S.}

To cite this article: J. Brown F.R.S. (1903) LXI. Removal of the voltaic potentialdifference by heating in oil , Philosophical Magazine Series 6, 5:29, 591-594, DOI: 10.1080/14786440309462961

To link to this article: http://dx.doi.org/10.1080/14786440309462961

曲 Published online: 15 Apr 2009.

Submit your article to this journal $[\pi$

Џ Article views: 2

Q View related articles $\square$

Citing articles: 4 View citing articles 5 
serration of radioactivity under the influence of the most varied conditions. It must be taken into account in cosmical physics. 'The maintenance of solar energy, for example, no longer presents any fundamental difficulty if the internal energy of the component elements is considered to be available, $i$.e if processes of sub-atomic change are going on, It is interesting to note that Sir Norman Jockyer has interpreted the results of his spectroscopic researches on the latter view (Inorganic Evolution, 1900) although he regards the temperature as the cause rather than the effect of the process.

McGill Unisersity, Montreal.

\section{Removal of the Voltaic Potential-Difference by Heating} in Uil. By J. Brown, F.K.S.*

TN 1879, at an early stage of my investigations on voltaic action $\dagger$, it was suggested that the difference of potential observed near the surfaces of dissimilar bodies in contact is due to chemical action of films condensed on their surfaces from the atmosphere or gas surrounding such bodies.

It was pointed out $\ddagger$ that such a condition of things is quite analogous to that of an ordinary voltaic cell divided by a non-conductor through its electrolyte, e. g., copper | electrolyte | air | electrolyte | zinc, the copper and zinc being in contact and the difference of potential being taken between the two air / electrolyte surfaces. The film is therefore probably of an electrolytic nature, thus falling in with Faraday's view $\S$ that "in considering this oxidation, or other direct action upon the METAL itself as the canse and source of the electric current, it is of the utmost importance to observe that the oxygen or other body must be in a peculiar condition, namely in the state of combination and not only so, but limited still further to such a state of combination and in such propartions as will constitute an electrolyte." In 1886 I explained $\|$ the important difference between my view and that of De La Rive, which latter included the formation of non-conducting oxide films on the metal surfaces as necessary to maintain the electrification. I sbowed $\pi$ experimentally that if the surfaces of the zinc and copper plates, arranged as in Volta's condenser, be nearly true planes and be brought sufficiently close together to allow their films to come in contact, but not the metals

* Comnunicated by the Author.

† Phil. Mag. vii. p. 111 (1879).

\$ Experimentul Researches, i. p. 273

\|I Proc. Roy. Scc. Ixi. p. 200 (1880).

† Ibid. p. 110.

II Ibid. p. 307 . 
themselves, a roltaic cell is produced of which the films are the electrolyte.

In $1888 \mathrm{I}$ tried the effect of freezing the films on a Volta condenser by subjecting it to a temperature of $-21^{\circ} \mathrm{C}$. as obtained by a mixture of ice and common salt, with indefinite results, owing perhaps to unsuitable apparatus.

In 1900 Majorana* published experiments sbowing that on cooling a zinc / gold couple to the temperature of liquid air, the volta effect was reduced from 88 volt to 05 volt, and rose again on the return to ordinary temperature to .75 volt. With couples of other metals similar results were obtained. This effect, in my opinion, corresponds with the cessation of chemical activity at the temperature employed.

To get rid of chemical action at the surfaces of the inetals by the removal of the chemically acting substance, many attempts have been made, chiefly by inclosing the couple in a vessel exhausted to a high degree or surrounding it with "pure" inert gases, but without success. Heating the metals has also been frequently tried, but the oxidation or other alteration of their surfaces at higher temperatures intervenes, precluding any true estimation of the effect sought to be investigated.

In order to avoid this source of error in the experiments now to be described, 1 immersed the couple in a bath of oil of high boiling-point.

The diagram represents in section a zinc-copper Volta condenser with plates $\mathrm{C}, \mathrm{Z} 11.4$ centimetres in diameter, screwed on the ends of iron rods A and B of which the lower is fixed and the npper slides in an insulated guide-tube. Means are provided for setting the plates parallel and at a minute distance apart. D represents an enamelled iron dish, a hole in the bottom of which provides for its being fixed between the zinc and the collar $i$ on rod $B$ so as to hold the oil.

Heavy petroleum known as Price's gas-engine oil was used. Owing to its viscosity the plates (having nearly true surfaces) could be only slowly separated, although radial grooves were cut in the zinc to permit the more easy penetration of the oil between the plates when these were being pulled apart.

The following is the order of experiment:-The plates, having been well cleaned with fine glass-paper, were set close together and connected one to each pair of quadrants of the electrometer. After momentarily connecting them together by a wire and then separating them in the usual way, in air,

* Accad. Lincei Atti, Aug. 19th, Sept. 2nd and 16th (1000). 
a deflexion of 140 was observed. Oil sufficient to cover both plates was then poured into the bath; and, on again connecting and separating the plates several times, the deflexion

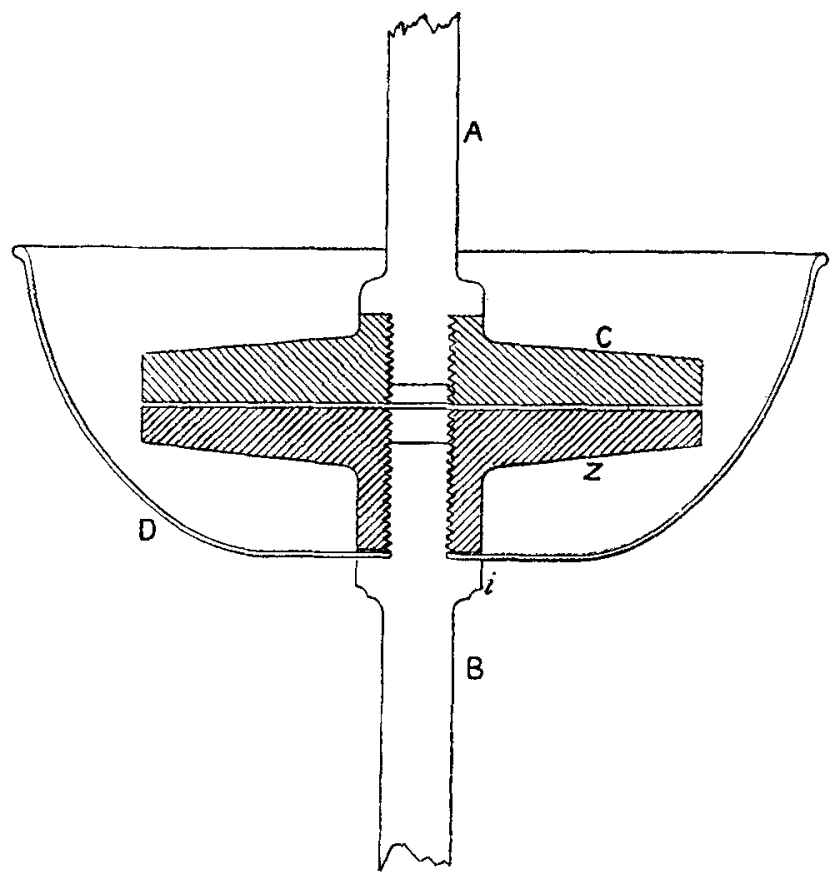

averaged 110 divisions in the same direction as before. The oil bath was then heated to about $145^{\circ} \mathrm{C}$, after which the connexion and separation gave no defexion. The whole was then allowed to cool and again tested, with the same result. The "volta effect" had disappeared. Its disappearance is apparently due to some effect of the heating since the mere immersion in the oil did not cause it, and its absence is not due to temperature merely, since this abseuce continued after the oil had cooled.

I take it that the volta effect ceased as soon as the condensed films were evaporated. If the disappearance of the volta effect had taken place immediately on immersion in the cold oil, it might have been considered to be caused by some conduction through the oil causing equalization of the potentials observed on air, as happens when plates in air are connected by a drop of water. There is, in fact, some such conduction of a very minute kind, the oil acting as an electrolyte and causing the combination to behave as a voltaic cell 
of exceedingly high resistance with an electromotive force of about 7 volt at first, falling after heating to about one-sixth of that amount. It may thus be noted that, this electromotive force is greatest at the time when its existence is seen to have little effect on the $\mathrm{p}$ int in question. In order, however, to finally obviate any conduction effect of this kind, the oil was removed and the plates carefully wiped with cotton-wool till nothing but a mere film of oil remained on their surfaces.

In the first experiment (No. 1) the volta effect was still absent when this had been done, but after one and a half hours, on testing again, I found it had returned and deflexions of abont 30 were obtained in the same direction as in air. I concluded that moisture from the atmosphere harl found opportunity to reach the zinc sufface in some quantity. In a repetition (No. 2) of the whole experiment the same effects were observed up till the removal of the oil, after which in this case, the return of the volta effect did not take place in four days, or if at all present, it was very slightly reversed. In this experiment the oil bad been kept at a high temperature for several hours and probably formed a more permanent protective film on the metallic surfaces. In a further experiment (No. 3) in which the high temperature was maintained only for a short period as in No. 1, the results again corroborated No. 1 only that the volta effect appeared still more quickly. In nine days after removal of the oil (except such oil films as adhered to the plates) it had regained almost its pristine value, the average deflexion being then about 130 .

At the conclusion of each of the three experiments, the zinc plate, on examination, appeared almost unaltered in appearance-only very slightly tarnished. On the copper there appeared to be a very thin transparent varnish-like film. On re-cleaning the plates with glass-paper the usual volta effect on air was observed.

'To sum up, I conclude that all the effects observed fall in satisfactorily with the condensed electrolyte-film theory as described above. On first immersion in cold oil the films continued to act in their usual way, as if in air, though with a somewhat less deffexion, probably owing to a minute conductivity in the oil somewhat reducing the difference of potential during the slow separation of the plates after metallic contact. When heated to above the boiling-point of water, the films evaporated and left nothing to effectively act electrolytically on the plates. After removal of the oil (unless a protective varnish-like film had been formed) the moisture of the air again found access to the surface and a difference of potential was again observed. 